\title{
The Inhibitory Activity of Banksia collina R.Br. and Banksia oblongifolia Cav. Methanolic Leaf Extracts against a Panel of Bacterial Pathogens
}

Ian Edwin Cock $\mathbf{k}^{1,2, *}$

'School of Environment and Science, Griffith University, Nathan, Brisbane, Queensland, AUSTRALIA.

2Environmental Futures Research Institute, Griffith University, Nathan, Brisbane, Queensland, AUSTRALIA.

\begin{abstract}
Introduction: The development of multi-antibiotic resistant strains of bacteria has necessitated the search for new, effective antibacterial therapies. $B$. collina and $B$. oblongifolia leaves were used by Australian Aborigines to treat bacterial infections. However, little research has been published on antibacterial activity of these species. Methods: The ability of $B . \mathrm{col}-$ lina and $B$. oblongifolia leaf extracts to inhibit the growth of gram-negative and gram-positive bacterial species was investigated by disc diffusion and growth time course assays. The growth inhibitory activity was further quantified by MIC determination. Toxicity was determined using the Artemia franciscana nauplii bioassay. Results: The B. collina and B. oblongifolia leaf extracts were good inhibitors of the growth of both gram-positive and gram-negative bacteria. The $B$. collina and $B$. oblongifolia leaf extracts were particularly good inhibitors of $A$. faecalis growth (MICs of 225 and $486 \mu \mathrm{g} /$ $\mathrm{mL}$ respectively) and $B$. cereus growth (MICs of 515 and $875 \mu \mathrm{g} / \mathrm{mL}$ respectively). The $B$. collina extract was also a good inhibitor of $B$. subtilis growth, whilst the $B$. oblongifolia extract was a moderate growth inhibitor (MIC values of 923 and $1250 \mu \mathrm{g} / \mathrm{mL}$ respectively). A similar, trend was noted for Y. entercolitica growth inhition (MICs of 518 and $1136 \mu \mathrm{g} / \mathrm{mL}$ respectively). Whilst MIC values were also determined against other bacterial species, they generally indicated low-moderate activity. The $B$. collina and $B$. oblongifolia leaf extracts were further investigated by growth time
\end{abstract}

course assays against $A$. faecalis and $B$. cereus. Interestingly, both extracts showed significant growth inhibition within $1 \mathrm{~h}$ of exposure against both bacterial species. All extracts were determined to be nontoxic in the Artemia franciscana nauplii bioassay, indicating their safety for the treatment of bacterial infections. Conclusion: The lack of toxicity of the B. collina and $B$. oblongifolia leaf extracts and their growth inhibitory bioactivity against multiple bacterial species indicate their potential in the development of new antibiotic chemotherapies.

Key words: Protaceae, Hill Banksia, Golden candlesticks Banksia, Fernleaved Banksia, Traditional medicine, Antibacterial activity, Antibiotic resistant bacteria, MIC

\section{Correspondence:}

Dr. Ian Edwin Cock

${ }^{1}$ School of Environment and Science, Griffith University, 170 Kessels Rd, Nathan, Brisbane, Queensland-4111, AUSTRALIA.

${ }^{2}$ Environmental Futures Research Institute, Griffith University, 170 Kessels Rd, Nathan, Brisbane, Queensland-4111, AUSTRALIA.

Phone no: +61737357637

E-mail: i.cock@griffith.edu.au

DOI: $10.5530 /$ pc.2020.1.6

\section{INTRODUCTION}

Despite many significant advances in the treatment of disease, illnesses caused by bacterial pathogens remain difficult to treat effectively. Many bacterial strains have gained resistance genes and have become either extremely (XDR) or totally drug resistant (TDR) to many antibiotics. ${ }^{1}$ There are now limited therapeutic options for the diseases caused by these pathogens and it is likely that this problem will worsen in the future as bacteria exchange resistance genes and more strains become multi-drug resistant (MDR). The development of alternative antibacterial treatment modalities has become crucial and is considered by the World Health Organisation (WHO) to be one of the most serious challenges facing medical science. ${ }^{2}$ For a number of reasons reviewed elsewhere, ${ }^{1}$ it is unlikely that the previous methods of antibiotic discovery/development will be as successful in the future and new treatment modalities are urgently required.

Plants produce a wide variety of secondary compounds that may provide them with antimicrobial properties. ${ }^{3}$ Traditional plant derived medicines have been used in most parts of the world for a variety of therapeutic purposes, including fighting microbial disease. Indeed, the ability of plant extracts to block the growth of pathogenic bacteria has become the focus of much recent study. ${ }^{4,5}$ Much of the research into traditional medicinal plant use has focused on Asian, ${ }^{6,7}$ African $^{8-12}$ and South American ${ }^{13,14}$ plants. However, the therapeutic potential of the flora of Australia has also received recent attention. The first Australians had well-developed medicinal systems and understood the therapeutic properties of a wide variety of Australian plants and how to use them effectively. ${ }^{15}$ Whilst studies have reported antibacterial activity for some
Australian plant species, ${ }^{16-19}$ the antibacterial activity of many Australian native plants remains unexamined.

Banksia collina R.Br. (Figure 1a; synonyms Banksia spinulosa var. collina (R.Br.) A.S. George; commonly known as hill banksia or golden candlesticks) and Banksia oblongifolia Cav. (Figure 1b; synonyms Banksia salicifolia Cav. Banksia latifolia var. minor Maiden and Camfield, Banksia robur var. minor (Maiden and Camfield) Maiden and Betche, Banksia integrifolia var. oblongifolia (Cav.) Domin; common known as fern-leaved, dwarf or rusty banksia) are endemic Australian plants and members of family Protaceae. Both species are native to coastal regions of eastern Australia, extending from the central New South Wales Coast north to the central Queensland coast. Interestingly, several Banksia spp. were used by the first Australians to treat bacterial infections. ${ }^{15,20}$ Furthermore, several studies have reported antibacterial activity for related Banksia spp. Extracts produced from Banksia intergrfolia var. aquilonia have good inhibitory activity against Bacillus cereus and Staphylococcus aureus (MIC values of 312 and $78 \mu \mathrm{g} / \mathrm{mL}$ respectively), as well as low-moderate activity against Escherichia coli. ${ }^{21}$ The same study reported that the same extract was ineffective against Streptococcus pneumonia and Pseudomonas aeruginosa. Studies into the antibacterial activity of many Australian Banksia spp. are lacking. The phytochemistry of Banksia spp. has been examined in the leaves of the related species Banksia coccinea R.Br. and Banksia menziesii R.Br. ${ }^{22}$ These species contain an abundance of anthocyanins including cyanidin-3-galactoside (Figure 1c), cyanidin-3-glucoside (Figure 1d), cyaniding-3,5-diglucoside Figure 1e), peonidin-3-galactoside (Figure 1f) and 
peonidin-3-glucoside (Figure 1g). Many similar flavonoids have good antibacterial activity. ${ }^{23}$ An examination of the antibacterial properties of Banksia spp. is therefore warranted. This study was undertaken to screen methanolic B. collina and B. oblongifolia leaf extracts for the ability to inhibit the growth of panels of gram-positive and gram-negative bacterial pathogens.

\section{MATERIALS AND METHODS}

\section{Plant collection and extraction}

Banksia collina R.Br. and Banksia oblongifolia Cav. leaves were obtained from verified plants in the Logan area south of Brisbane. The leaf samples were dried in a Sunbeam food dehydrator and stored at $-30^{\circ} \mathrm{C}$. Prior to use, the dried leaves were freshly ground to a coarse powder and $1 \mathrm{~g}$ quantities were weighed into separate tubes. A volume of $50 \mathrm{~mL}$ of AR grade methanol (Ajax Fine Chemicals, Australia) was added to $1 \mathrm{~g}$ of the plant material and extracted for $24 \mathrm{hr}$ at $4^{\circ} \mathrm{C}$ with gentle shaking. The extract was filtered through filter paper (Whatman No. 54) under vacuum, followed by lyophilisation. The resultant pellets were weighed to determine the extraction yield and subsequently dissolved in $10 \mathrm{~mL}$ sterile deionised water (containing 1\% DMSO). The extracts were passed through $0.22 \mu \mathrm{m}$ filter (Sarstedt) and stored at $4^{\circ} \mathrm{C}$ until use.

\section{Qualitative phytochemical studies}

Phytochemical analysis of the $B$. collina and $B$. oblongifolia leaf extracts for the presence of saponins, phenolic compounds, flavonoids, phytosteroids, triterpenoids, cardiac glycosides, anthraquinones, tannins and alkaloids was conducted by standard assays. ${ }^{24,25}$

\section{Antibacterial screening Test microorganisms}

All media was purchased from Oxoid Ltd., Australia. The reference strains of E. coli (ATCC157293), Klebsiella pneumoniae (ATCC31488), Proteus mirabilis (ATCC21721) and Streptococcus pyogenes (ATCC19615) were purchased from American Tissue Culture Collection (ATCC), USA. All other bacterial strains used in this study were clinical isolate microbial strains and were obtained from Ms Michelle Mendell and Ms Jane Gifkins, Griffith University. All stock cultures were subcultured and maintained in nutrient broth at $4^{\circ} \mathrm{C}$.

\section{Evaluation of antimicrobial activity}

Antimicrobial activity of the B. collina and B. oblongifolia leaf extracts was determined using a modified disc diffusion assay. ${ }^{26-28}$ Briefly, $100 \mu \mathrm{L}$ of the each bacterial suspension in log phase was spread onto individual nutrient agar plates and the extracts were tested for antibacterial activity using $6 \mathrm{~mm}$ sterilised filter paper discs. The discs were each infused with $10 \mu \mathrm{L}$ of the individual plant extract, allowed to dry and placed onto the inoculated plates. The plates were allowed to stand at $4^{\circ} \mathrm{C}$ for $2 \mathrm{hr}$ before incubation at $37^{\circ} \mathrm{C}$ for $24 \mathrm{hr}$. The diameters of the zones of inhibition (ZOIs) were measured to the closest whole millimetre. Each assay was performed three times in triplicate $(n=9)$. Mean values $( \pm$ SEM) are reported in this study. Standard discs of ampicillin $(10 \mu \mathrm{g})$ and chloramphenicol $(10 \mu \mathrm{g})$ were obtained from Oxoid, Australia and were used as positive controls to compare antibacterial activity. Filter discs infused with $10 \mu \mathrm{L}$ of distilled water were used as a negative control.

\section{Minimum inhibitory concentration (MIC) determination}

The minimum inhibitory concentration (MIC) of each extract against susceptible bacteria was determined as previously described. ${ }^{29,30}$ Briefly, the B. collina and B. oblongifolia leaf extracts were diluted in deionised water (1\% DMSO) and tested across a range of concentrations. Discs were individually infused with $10 \mu \mathrm{L}$ of each extract, allowed to dry and placed onto the inoculated plates. The assay was completed as outlined above and graphs of the ZOI versus ln concentration were plotted for each extract. Linear regression was used to determine the MIC values of each extract.

\section{Bacterial growth time course assay}

Bacterial growth time course studies were performed as previously described. ${ }^{31}$ Briefly, $3 \mathrm{~mL}$ of the gram-positive bacterial species in nutrient broth were individually added to $27 \mathrm{~mL}$ nutrient broth containing $3 \mathrm{~mL}$ of $10 \mathrm{mg} / \mathrm{mL}$ of the extract to give a final extract concentration of $1000 \mu \mathrm{g} /$ $\mathrm{mL}$ in the assay. The tubes were incubated at $37^{\circ} \mathrm{C}$ with gentle shaking. The optical density was measured hourly at $550 \mathrm{~nm}$ for a $6 \mathrm{~h}$ incubation period. Control tubes were incubated under the same conditions but without the extract. All assays were performed three times in triplicate $(n=9)$.

\section{Toxicity screening}

\section{Artemia franciscana nauplii toxicity screening}

Toxicity was tested using an adapted Artemia franciscana nauplii lethality assay. ${ }^{32,33}$ Briefly, $A$. franciscana nauplii were incubated in the presence of the extracts, reference toxin $(1 \mathrm{mg} / \mathrm{mL}$ potassium dichromate) or artificial seawater (negative control) at $25 \pm 1^{\circ} \mathrm{C}$ under artificial light. All treatments were performed three times in triplicate $(n=9)$. The number of dead nauplii were counted in each well at 24,48 and $72 \mathrm{hr}$. At the completion of the $72 \mathrm{hr}$ exposure period, the remaining live nauplii were sacrificed and the total number of nauplii in each well were counted and used to calculate the $\%$ mortality per well. $\mathrm{LC}_{50}$ values were calculated for each treatment using probit analysis.

\section{Statistical analysis}

Data are expressed as the mean \pm SEM of three independent experiments with internal triplicates $(n=9)$. One-way ANOVA was used to calculate statistical significance between control and treated groups, with a $P$ value $<0.01$ considered to be statistically significant.

\section{RESULTS}

\section{Liquid extraction yields and qualitative phytochemical screening}

Extraction of $1 \mathrm{~g}$ of dried and powdered B. collina and B. oblongifolia leaf extracts with methanol yielded 299 and $236 \mathrm{mg}$ of extracted material respectively (Table 1). The extracts were resuspended in $10 \mathrm{~mL}$ of deionised water (containing 1\% DMSO), resulting in an extract concentrations shown in Table 1. Qualitative phytochemical screening studies showed that both extracts had similar phytochemical profiles. Both contained high levels of phenolic compounds and flavonoids. Lower levels of saponins, triterpenoids and tannins were also detected. Cardiac glycosides, phytosterols, alkaloids and anthraquinones were completely absent or below the detection thresholds for these assays.

\section{Antimicrobial activity}

To determine the growth inhibitory activity of the $B$. collina and $B$. oblongifolia leaf extracts, aliquots $(10 \mu \mathrm{L})$ of each extract were screened in the disc diffusion assay. The B. collina and B. oblongifolia leaf extracts were effective at inhibiting the growth of 4 of the $5(80 \%)$ gram-negative bacterial species tested (Figure 2). For all of the inhibited bacteria, the $B$. collina extract was a substantially more potent inhibitor of bacterial growth than the B. oblongifolia extract. Only E. coli was completely resistant to the B. collina and B. oblongifolia leaf extracts. In contrast, A. faecalis was highly susceptible to the B. collina and B. oblongifolia leaf extracts, with ZOIs of 17.3 and $11.6 \mathrm{~mm}$. This compared well to the ZOIs of the 


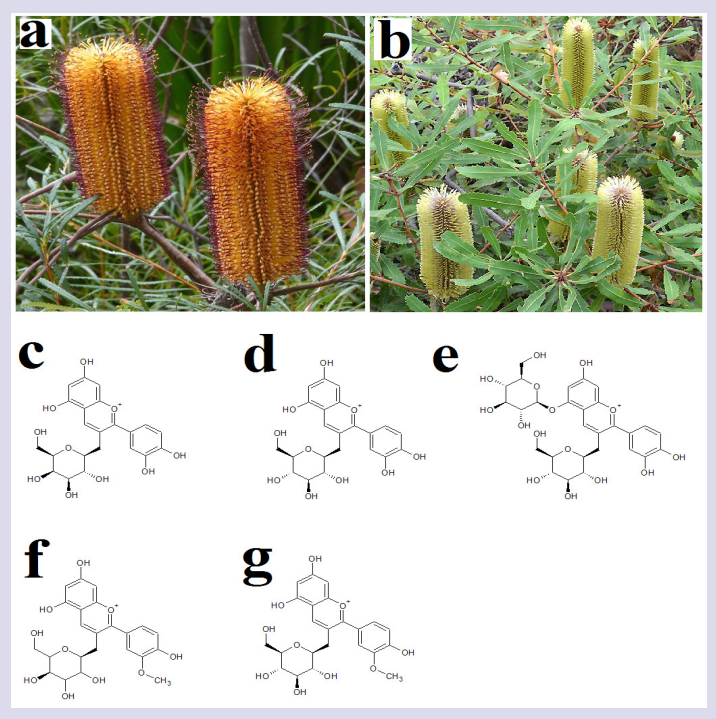

Figure 1: (a) B. collina, (b) B. oblongifolia, as well as the anthocyanins (c) cyanidin-3-galactoside, (d) cyanidin-3-glucoside, (e) cyaniding-3,5diglucoside, (f) peonidin-3-galactoside and (g) peonidin-3-glucoside.

control antibiotics, indicating that this extract may be particularly useful in the development of future antibiotic therapies. The ampicillin control was a potent inhibitor of $A$. faecalis growth, with a ZOI's of $15.3 \mathrm{~mm}$. This bacterium was relatively resistant to chloramphenicol, with only $6.6 \mathrm{~mm}$ ZOIs recorded. Notably, the control antibiotics were tested at a relatively high dosage $(10 \mu \mathrm{g} / \mathrm{disc})$ of pure antibiotic. In contrast, the extracts were crude and the antibacterial component(s) would be expected to contain a relatively low $\%$ of the bioactive compound(s). Similar results, albeit with smaller ZOIs, were noted for the collina and B. oblongifolia leaf extracts against $K$. pneumonia, P. mirabilis and Y. entercolitica.

The gram-positive bacterial species were also susceptible to the $B$. collina and B. oblongifolia leaf extracts. The growth of 3 of the $5(60 \%)$ gram-positive bacterial species tested were susceptible to at least one of the extracts (Figure 3). As noted for the gram-negative bacteria, the B. collina extract was generally a substantially better inhibitor of gram-positive bacterial growth than the B. oblongifolia extracts. B. cereus was the most susceptible to the inhibitory effects of the extracts, with ZOIs of nearly 10.6 and $9.2 \mathrm{~mm}$ measured respectively (Figure 3). These ZOIs are comparable to those of the pure ampicillin and chloramphenicol (14.6 and $11.3 \mathrm{~mm}$ respectively). This is noteworthy as the antibiotic controls were tested at relatively high doses $(10 \mu \mathrm{g} / \mathrm{disc})$. Furthermore, the control antibiotics are pure compounds, whereas the extracts are crude mixtures and the active compound(s) would be expected to be a minor $\%$ of the overall extracts mass. Therefore, these extracts may be particularly promising as targets for antibiotic drug discovery. The B. collina and B. oblongifolia leaf extracts were also effective inhibitors of $B$. subtilis growth (Figure 3 ), albeit with a smaller ZOI noted ( 8.8 and $7.6 \mathrm{~mm}$ respectively). The $B$. collina (but not the B. oblongifolia) leaf extract also inhibited $S$. pyogenes growth, albeit with a ZOI that is indicative of low to moderate inhibitory activity. As $S$. pyogenes can cause a wide variety of diseases including pharyngitis, impetigo and rheumatic fever depending on the tissue that it infects, the $B$. collina extract may be useful as targets for antibiotic discovery. In contrast, both Staphylococcus spp. were resistant to the $B$. collina and B. oblongifolia leaf extracts.

The antimicrobial efficacy was further quantified by determining MIC values. The $B$. collina and $B$. oblongifolia leaf extracts were particularly good inhibitors of $A$. faecalis (MICs of 225 and $486 \mu \mathrm{g} / \mathrm{mL}$ respectively)

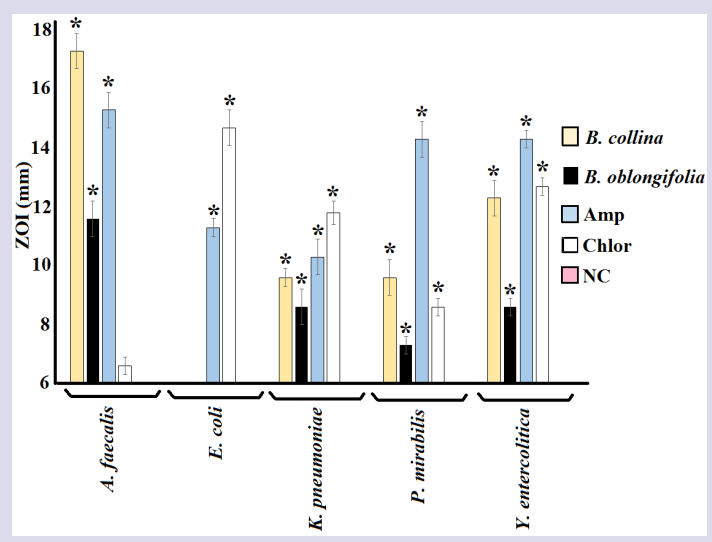

Figure 2: Growth inhibitory activity of the B. collina and B. oblongifolia leaf extracts extracts and reference antibiotics against gram-negative bacterial species measured as ZOIs ( $\mathrm{mm}) \pm \mathrm{SEM}$. Ampicillin (Amp) and chloramphenicol (Chlor) standard discs $(10 \mu \mathrm{g})$ were used as positive controls. All assays were completed three times, each with internal triplicates $(n=9)$ and the results are expressed as mean zones of inhibition $(\mathrm{mm}) \pm$ SEM. * indicates results that were significantly different to the untreated control $(P<0.01)$

and $B$. cereus growth (MICs of 515 and $875 \mu \mathrm{g} / \mathrm{mL}$ respectively). The $B$. collina extracts were also a good inhibitor of $B$. subtilis growth, whilst the B. oblongifolia extract was a moderate growth inhibitor (MIC values of 923 and $1250 \mu \mathrm{g} / \mathrm{mL}$ respectively). A similar, trend was noted for $Y$. entercolitica growth inhition (MICs of 518 and $1136 \mu \mathrm{g} / \mathrm{mL}$ respectively). Whilst MIC values were also determined against other bacterial species, they generally indicated moderate-low activity.

\section{Bacterial growth time course assay}

The antibacterial activity of the B. collina and B. oblongifolia leaf extracts was further investigated against $A$. faecalis and $B$. cereus by bacterial growth time course assays in the presence and absence of the extracts (Figure 4). The starting concentration of the extract used in these assays was $1000 \mu \mathrm{g} / \mathrm{mL}$. The B. collina and B. oblongifolia leaf extracts both significantly inhibited $A$. faecalis within $1 \mathrm{hr}$ of exposure, indicating a rapid antimicrobial action (Figure 4a). The absorbance of the $A$. faecalis culture remained substantially lower than the untreated control for the first $4 \mathrm{hr}$ of exposure. After that time, the absorbance increased to approximately the same level as the control, indicating that the B. collina and $B$. oblongifolia leaf extracts are bacteriostatic rather than bacteriocidal at the concentrations tested. Similar trends were noted when the B. collina and $B$. oblongifolia leaf extracts were tested against B. cereus (Figure $4 b$ ). Again, the absorbance of the B. cereus culture (and thus the bacterial growth) remained substantially lower than the untreated control for the first $4 \mathrm{hr}$ of exposure and then increased to approximately the same level as the control, indicating that B. collina and B. oblongifolia leaf extracts may be bacteriostatic at the concentrations tested (Figure $4 \mathrm{~b}$ ).

\section{Quantification of toxicity}

The toxicity of the B. collina and B. oblongifolia leaf extracts extracts was initially tested at $2 \mathrm{mg} / \mathrm{mL}$ in the $A$. franciscana nauplii bioassay (Figure $5)$. The mortality in the presence of both extracts was not significantly different to that of the untreated control at $24 \mathrm{hr}$ and thus they were deemed to be non-toxic. Extracts with $24 \mathrm{~h} \mathrm{LC}_{50}$ values $>1000 \mu \mathrm{g} / \mathrm{mL}$ have previously been defined as non-toxic. ${ }^{32,33}$ In contrast, the potassium dichromate positive control induced substantial mortality within $4 \mathrm{hr}$ (results not shown), with $100 \%$ mortality induction seen by $24 \mathrm{hr}$. The 


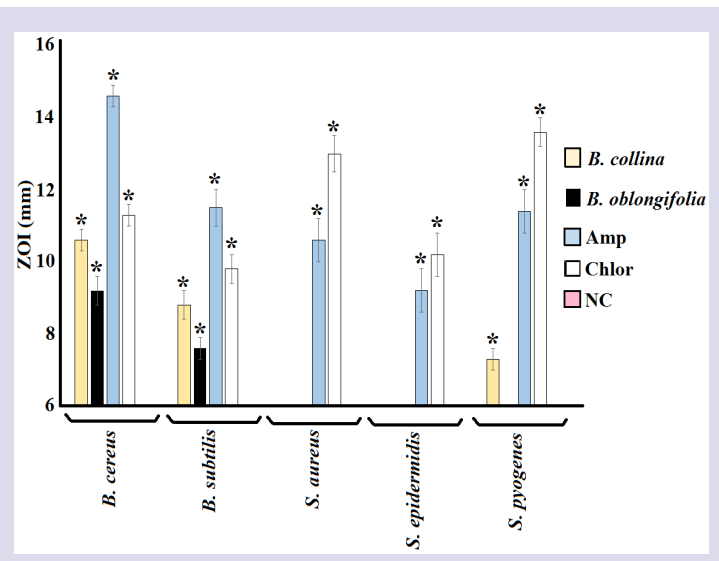

Figure 3: Growth inhibitory activity of the B. collina and B. oblongifolia leaf extracts extracts and reference antibiotics against gram-positive bacterial species measured as ZOls $(\mathrm{mm}) \pm \mathrm{SEM}$. Ampicillin (Amp) and chloramphenicol $(\mathrm{Chl})$ standard discs $(10 \mu \mathrm{g})$ were used as positive controls. NC = negative control. All assays were completed three times, each with internal triplicates $(n=9)$ and the results are expressed as mean zones of inhibition $(\mathrm{mm}) \pm S E M$. * indicates results that were significantly different to the untreated control $(P<0.01)$.
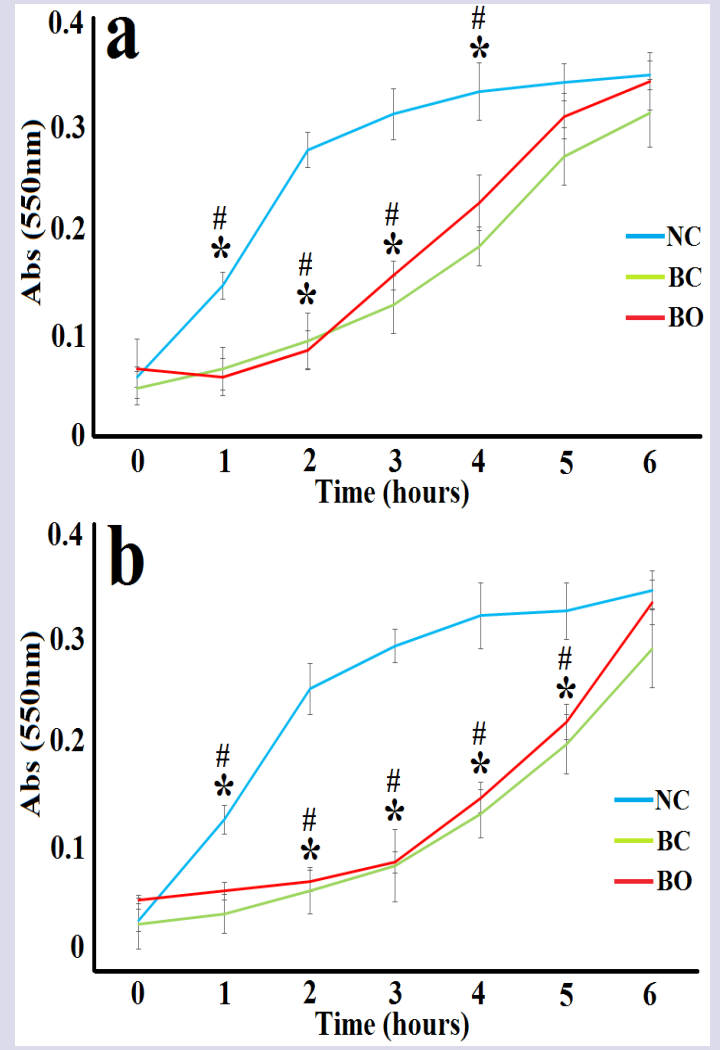

Figure 4: Bacterial growth curves the $B$. collina and $B$. oblongifolia leaf extracts against (a) $A$. faecalis and (b) B. cereus. All bioassays were performed three times in triplicate $(n=9)$ and are expressed as mean \pm $\mathrm{SEM} . \mathrm{BC}=$ B. collina extract; $\mathrm{BO}=$ B. oblongifolia extract; ${ }^{*}=$ methanolic extract results that are significantly different between the treated and the untreated control growth; \# = aqueous extract results that are significantly different between the treated and the untreated control growth $(P<0.01)$.

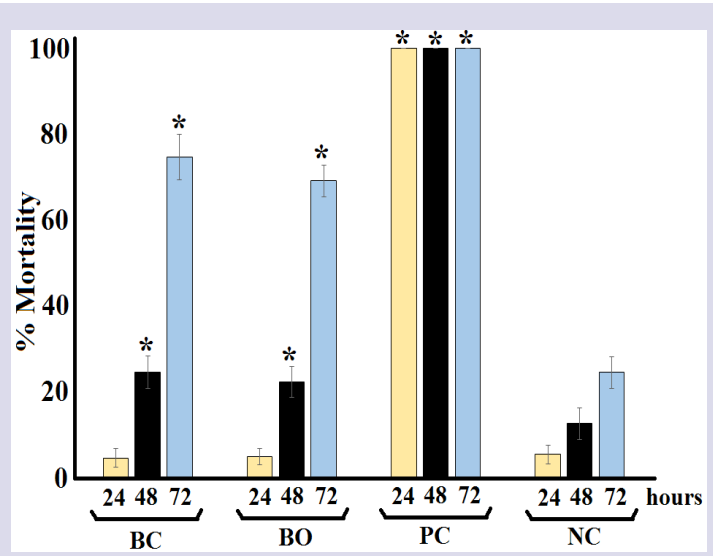

Figure 5: The lethality of the $B$. collina and $B$. oblongifolia leaf extracts $(2000 \mu \mathrm{g} / \mathrm{mL})$, potassium dichromate control $(1000 \mu \mathrm{g} / \mathrm{mL})$ and seawater (negative control) following 24, 48 and $72 \mathrm{hr}$ exposure. BC = Banksia collina extract; $\mathrm{BO}=$ Banksa oblongifolia extract; $\mathrm{PC}=$ potassium dichromate control; $\mathrm{NC}=$ negative (seawater) control. All bioassays were performed three times in triplicate $(n=9)$ and are expressed as mean \pm SEM. * indicates results that are significantly different to the untreated (seawater) control at the equivalent exposure time $(P<0.01)$. mortality induction remained low for the B. collina and B. oblongifolia leaf extracts at $48 \mathrm{hr}$. Indeed, the $\%$ mortality induction was substantially $<50 \%$ for all extracts at all times tested and therefore it was not possible to determine $\mathrm{LC}_{50}$ values for any of the B. collina and B. oblongifolia leaf extracts (Table 2).

\section{DISCUSSION}

Despite the initial potency of many antibiotic chemotherapies, recent increases in bacterial resistance has made the development of new antibiotic therapies a high priority. ${ }^{1}$ A parallel decrease in the introduction of new antibiotic therapies in recent years has further compounded this problem. As a result, interest in re-evaluating medicinal plants for new antibiotic chemotherapies has escalated substantially. ${ }^{34}$ The first Australians used several Banksia spp. to treat multiple diseases and infections caused by bacterial pathogens. ${ }^{15,20}$ Despite this, limited scientific evaluations have rigorously evaluated the antibacterial properties of other Banksia spp. To the best of our knowledge, this is the first study to report bacterial growth inhibitory activity of $B$. collina and B. oblongifolia.

The ability of the B. collina and B. oblongifolia leaf extracts to inhibit the growth of both gram-positive and gram-negative bacteria is in agreement with previous reports of the antibacterial activity of other Australian plant species. ${ }^{35,36}$ In our study, the gram-negative and gram-positive bacteria were approximately equally susceptible to the $B$. collina and $B$. oblongifolia extracts. In contrast, many previous studies have reported substantially greater susceptibility for gram-positive bacteria to South American, ${ }^{13,14}$ African, ${ }^{11,12}$ and Australian ${ }^{37}$ plant extracts. Results within our laboratory have also confirmed the greater susceptibility of grampositive bacteria towards many other Australian plant extracts. ${ }^{38,39}$ The gram-negative bacterial cell wall outer membrane is thought to act as a barrier to many substances including several antibiotics. ${ }^{40}$ In contrast, other studies have demonstrated that gram-negative bacteria are often as susceptible (or more susceptible) to plant extracts from different Australian plant species. ${ }^{41,42}$

Whilst an investigation of the phytochemistry of the B. collina and $B$. oblongifolia leaf extracts was beyond the scope of this study, moderate to 
Table 1: The mass of dried extracted material, the concentration after resuspension in deionised water and qualitative phytochemical screenings of the $B$. collina and $B$. oblongifolia leaf extracts.

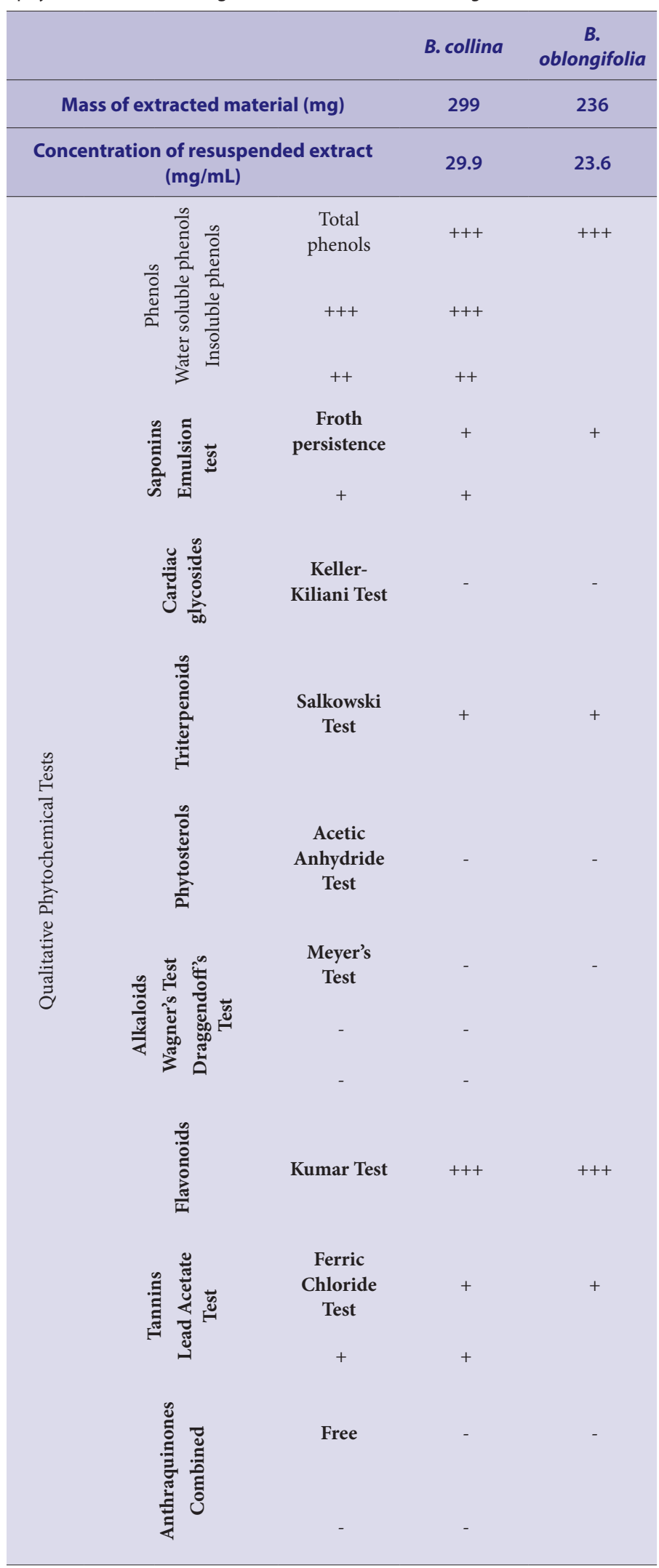

+++ indicates a large response; ++ indicates a moderate response; + indicates a minor response; - indicates no response in the assay.
Table 2: Minimum inhibitory concentrations $(\mu \mathrm{g} / \mathrm{mL})$ of the $B$. collina and $B$. oblongifolia leaf extracts against each bacterial strain and $\mathrm{LC}_{50}$ values $(\mu \mathrm{g} /$ $\mathrm{mL}$ ) against Artemia nauplii.

\begin{tabular}{cccc|}
\hline \multirow{2}{*}{ Organism } & Exposure time & \multicolumn{2}{c|}{ MIC or $\mathbf{L C}_{\mathbf{5 0}}(\mathbf{\mu g} / \mathbf{m L})$} \\
\cline { 3 - 4 } & $(\mathbf{h})$ & B. collina & B. oblongifolia \\
\hline A. faecalis & 24 & 225 & 486 \\
E. coli & 24 & - & - \\
K. pneumoniae & 24 & 1134 & 1583 \\
P. mirabilis & 24 & 1426 & 1830 \\
Y. entercolitica & 24 & 518 & 1136 \\
B. cereus & 24 & 515 & 875 \\
B. subtilis & 24 & 923 & 1250 \\
S. aureus & 24 & - & - \\
S. epidermidis & 24 & - & - \\
S. pyogenes & 24 & 1352 & - \\
& 24 & $\mathrm{CND}$ & $\mathrm{CND}$ \\
Artemia nauplii & 48 & $\mathrm{CND}$ & $\mathrm{CND}$ \\
& 72 & 1343 & 1580 \\
\hline
\end{tabular}

Numbers indicate the mean MIC or $\mathrm{LC}_{50}$ values of three independent experiments in triplicate $(n=9)$. - indicates that an the extract did not inhibit bacterial growth at any concentration tested; CND indicates that an $\mathrm{LC}_{50}$ could not be determined as the mortality did not exceed $50 \%$ at any concentration tested.

high levels of polyphenolics and flavonoids were noted in the extracts by qualitative phytochemical screening. Lower levels of saponins, triterpenoids and tannins were also detected. Previous studies have also reported that Banksia spp. are a relatively rich source of anthocyanin flavonoids. ${ }^{22}$ Flavonoids have well established bacterial growth inhibitory activities. ${ }^{23}$ The flavonoids kaempferol and myricetin have been reported to be potent growth inhibitors of a panel of bacterial pathogens. ${ }^{43}$ Similarly, quercetin, rutin and their corresponding glycosides inhibit the growth of Pseudomonas maltophilia and Enterobacter cloacae. ${ }^{44}$ It is therefore likely that the B. collina and B. oblongifolia leaf extract flavonoids may contribute to the antibacterial activity reported in this study. However, it is likely that other phytochemical classes in these extracts may also contribute to the antibacterial activity.

The antimicrobial activity of terpenoids has also been extensively documented. Monoterpenoids including $\alpha$-pinene, $\beta$-pinene, sabinene, mycrene, terpinene, limonene, piperitone and $\beta$-phellandrene inhibit the growth of a panel of bacteria, including several antibiotic resistant strains of Enterobacteriaceae. ${ }^{23}$ The antibacterial activities for several sesquiterpenoids including $\alpha$-cubebene, copaene and caryophyllene have been reported. ${ }^{23}$ Similarly, many tannin compounds have bacterial growth inhibitory activity. Gallotannins inhibit the growth of a broad spectrum of bacterial species ${ }^{45}$ through a variety of mechanisms including binding cell surface molecules including lipotoichoic acid and proline-rich cell surface proteins, ${ }^{46,47}$ and by inhibiting glucosyltransferase enzymes. ${ }^{48}$ Elligitannins are also highly potent inhibitors of bacterial growth, with MIC values as low as $62.5 \mu \mathrm{g} / \mathrm{mL} .^{45,46}$ Ellagitannins have also been reported to function via several antibiotic mechanisms including interaction with cytoplasmic oxidoreductases and by disrupting bacterial cell walls. ${ }^{45,47}$ Thus, it is likely that multiple compounds within the B. collina and B. oblongifolia leaf extracts are contributing to the antibacterial activity reported here.

The findings reported here also indicate that the extracts examined were non-toxic $\left(\mathrm{LC}_{50}>1000 \mu \mathrm{g} / \mathrm{mL}\right.$ ) in the Artemia nauplii bioassay. Whilst 
toxicity was assessed in this study with the test organism A. franciscana, toxicity towards $A$. franciscana has previously been shown to correlate well with toxicity towards human cells for many toxins. ${ }^{32,33}$ However, further studies are required to determine whether this is also true for the B. collina and B. oblongifolia leaf extracts examined in these studies. The results of this study indicate that the B. collina and B. oblongifolia leaf extracts may be good candidates for antimicrobial drug discovery and further examination is warranted. Whilst the extracts examined in this report have potential as bacterial growth inhibitors, caution is needed before these compounds can be applied to medicinal purposes. Purification and identification of the bioactive components is needed to examine the mechanisms of action of these agents.

\section{CONCLUSION}

The growth inhibitory activity of the B. collina and B. oblongifolia leaf extracts against gram-positive and gram-negative bacteria and their lack of toxicity indicate their potential for the development of novel chemotherapies to treat a variety of diseases caused by bacterial pathogens. Further studies aimed at the purification of the bioactive components are needed to examine the mechanisms of action of these agents.

\section{ACKNOWLEDGEMENT}

The authors are grateful to Michelle Mendell and Jane Gifkins of Griffith University for providing the clinical bacterial strains used in this study. Financial support for this work was provided by the Environmental Futures Research Institute and the School of Natural Sciences, Griffith University, Australia.

\section{CONFLICT OF INTEREST}

The authors report no conflicts of interest.

\section{ABBREVIATIONS}

DMSO: Dimethyl sulfoxide; $\mathbf{L C}_{50}$ : The concentration required to achieve $50 \%$ mortality; MIC: Minimum inhibitory concentration; ZOI: Zone of inhibition.

\section{REFERENCES}

1. Cheesman MJ, Ilanko A, Blonk B, Cock IE. Developing new antimicrobial therapies: Are synergistic combinations of plant extracts/compounds with conventional antibiotics the solution?. Pharmacog Rev. 2017;11(22):57-72. DOI: 10.4103/phrev.phrev_21_17

2. WHO. Antimicrobial Resistance. World Health Organization. 2016. Available from: http://www.who.int/mediacentre/factsheets/fs194/en/. [Cited on 2017 May 10].

3. Cowan MM. Plant products as antibacterial agents. Clin Microbiol Rev. 1999;12(4):564-82

4. Bhavnani SM, Ballow $\mathrm{CH}$. New agents for Gram-positive bacteria. Curr Opin Microbiol. 2000;3(5):528-34.

5. Chiariandy $\mathrm{CM}$, Seaforth $\mathrm{CE}$, Phelps $\mathrm{RH}$, et al. Screening of medicinal plants from Trinidad and Tobago for antimicrobial and insecticidal properties. J Ethnopharmacol. 1999;64(3):265-70.

6. Hart C, Cock IE. An examination of the antimicrobial and anticancer properties of Garcinia cambogia fruit pericarp extracts. BEMS Reports. 2016;2(1):23-6. DOI: 10.5530/BEMS.2016.1.5

7. Wright MH, Arnold MSJ, Lee CJ, et al. Qualitative phytochemical analysis and antibacterial activity evaluation of Indian Terminalia spp. against the pharyngitis causing pathogen Streptococcus pyogenes. Pharmacog Commn. 2016;6(2):8592. DOI: $10.5530 / p c .2016 .2 .6$

8. Hübsch Z, ZyI RLV, Cock IE, et al. Interactive antimicrobial and toxicity profiles of conventional antimicrobials with Southern African medicinal plants. S Afr J Bot. 2014;93:185-97. DOI: 10.1016/j.sajb.2014.04.005

9. Arkhipov A, Sirdaarta J, Rayan P, et al. An examination of the antibacterial, antifungal, anti-Giardial and anticancer properties of Kigelia africana fruit extracts. Pharmacog Commn. 2014;4(3):62-76. DOI: 10.5530/pc.2014.3.7

10. Rabadeaux C, Vallette L, Sirdaarta J, et al. An examination of the antimicrobial and anticancer properties of Khaya senegalensis (Desr.) A. Juss. bark extracts Pharmacog J. 2017;9(2):175-84. DOI: 10.5530/pj.2017.4.82

11. Cock IE, van Vuuren SF. Anti-Proteus activity of some South African medicinal plants: Their potential for the treatment and prevention of rheumatoid arthritis. Inflammopharmacol. 2014;22(1):23-36. DOI 10.1007/s10787-013-0179-3

12. Cock IE, van Vuuren SF. The potential of selected some South African plants with anti-Klebsiella activity for the treatment and prevention of ankylosing spondylitis. Inflammopharmacol. 2015;23(1):21-35. DOI: 10.1007/s-10787-0130179-3

13. Mohanty S, Cock IE. Evaluation of the antibacterial activity and toxicity of Myrciaria caulifloria methanolic leaf and fruit extracts. Int J Microbiol. 2009;7(2):1-8.

14. Paz EA Cerdeiras MP, Fernandez $\mathrm{J}$, et al. Screening of Uruguayan medicinal plants for antimicrobial activity. J Ethnopharmacol. 1995;45(1):67-70.

15. Cock IE. Medicinal and aromatic plants-Australia. In Ethnopharmacology, Encyclopedia of Life Support Systems (EOLSS): Developed under the auspices of UNESCO. Oxford, UK: EOLSS Publishers. 2011. Available from: http://www. eolss.net.

16. Sirdaarta J, Matthews B, Cock IE. Inhibitory activity of Kakadu plum fruit extracts against microbial triggers of rheumatoid arthritis: Identification of stilbene and tannin components. J Funct Foods. 2015;17:610-20.

17. Winnett $V$, Sirdaarta J, White A, et al. Inhibition of Klebsiella pneumonia growth by selected Australian plants: Natural approaches for the prevention and management of ankylosing spondylitis. Inflammopharmacol. 2017:25:223-35. DOI: 10.1007/s10787-017-0328-1

18. Wright $\mathrm{MH}$, Matthews $\mathrm{B}$, Arnold MSJ, et al. The prevention of fish spoilage by high antioxidant Australian culinary plants: Shewanella putrefaciens growth inhibition. Int J Food Sci and Technol. 2016;51(3):801-13. DOI: 10.1111/ijfs.13026

19. Ilanko A, Cock IE. The interactive antimicrobial activity of contentional antibiotics and Petalostigma spp. Extracts against bacterial triggers of some autoimmune inflammatory diseases. Pharmacog J. 2019;11(2):292-309.

20. Lassak EV, McCarthy T. Australian Medicinal Plants. New Holland Publishers Sydney Australia. 2011.

21. Setzer MC, Setzer WN, Jackes BR, et al. The medicinal value of tropical rainforest plants from Paluma, North Queensland, Australia. Pharm Biol. 2001;39(1):67-78

22. Asenstorfer RE, Morgan AL, HayasakaY, et al. Purification of anthocyanins from species of Banksia and Acacia using high-voltage paper electrophoresis. Phytochemical Analysis: Int J Plant Chem Biochem Tech. 2003;14(3):150-4.

23. Cock IE. The phytochemistry and chemotherapeutic potential of Tasmannia lanceolata (Tasmanian pepper): A review. Pharmacog Commn. 2013;3(4):13-25. DOI: $10.5530 / p c .2013 .4 .3$

24. Vesoul J, Cock IE. An examination of the medicinal potential of Pittosporum phylloraeoides: Toxicity, antibacterial and antifungal activities. Pharmacog Commn. 2011;1(2):8-17. DOI: 10.5530/pc.2012.1.13

25. Kukkonen L, Cock IE. An examination of the medicinal potential of Scaevola spinescens: Toxicity, antibacterial and antiviral activities. Pharmacog Res. 2011;3(2):85-94. DOI: 10.4103/0974-8490.81955

26. Sirdaarda J, Matthews B, White A, et al. GC-MS and LC-MS analysis of Kakadu plum fruit extracts displaying inhibitory activity against microbial triggers of multiple sclerosis. Pharmacog Commn. 2015;5(2):100-15. DOI: 10.5530/pc.2015.2.2

27. Maen A, Cock IE. Inhibitory activity of Australian cullinary herb extracts against the bacterial triggers of selected autoimmune diseases. Pharmacog Commn. 2015;5(2):130-9. DOI: 10.5530/pc.2015.2.4

28. Mpala L, Chikowe G, Cock IE. No evidence of antiseptic properties and low toxicity of selected Aloe species. J Pharm Negative Results. 2010;1(1):10-6. DOI: 10.4103/0976-9234.68869

29. Kalt FR, Cock IE. Gas chromatography-mass spectroscopy analysis of bioactive Petalostigma extracts: Toxicity, antibacterial and antiviral activities. Pharmacog Mag. 2014;10(Suppl 1):S37-49. DOI: 10.4103/0973-1296.127338

30. Cock IE, Winnett V, Sirdaarta J, et al. The potential of selected Australian medicinal plants with anti-Proteus activity for the treatment and prevention of rheumatoid arthritis. Pharmacog Mag. 2015;11(42 Suppl 1):S190-208. DOI: 10.4103/0973-1296.157734

31. Cock IE. Antimicrobial activity of Callistemon citrinus and Callistemon salignus methanolic extracts. Pharmacog Commn. 2012;2(3):50-7. DOI: 10.5530/ pc.2012.3.11

32. Ruebhart DR, Wikramasinghe WA, Cock IE. Protective efficacy of the antioxidants vitamin $\mathrm{E}$ and Trolox against Microcystis aeruginosa and microcystin-LR in Artemia franciscana nauplii. J Toxicol Environ Health Part A. 2009;72(24):156775.

33. Cock IE, Ruebhart DR. Comparison of the brine shrimp nauplii bioassay and the ToxScreen-II test for the detection of toxicity associated with Aloe vera (Aloe barbadensis Miller) leaf extract. Pharmacog Res. 2009;1(2):98-101.

34. Aiyegoro OA, Okoh Al. Use of bioactive plant products in combination with standard antibiotics: Implications in antimicrobial chemotherapy. J Med Plant Res. 2009;3(13):1147-52.

35. Cock IE. Antibacterial activity of selected Australian plant species. The Int $J$ Microbiol. 2008;6:2. 
36. Kalt FR, Cock IE. The medicinal potential of Australian native plants from Toohey Forest, Australia. SPJNS. 2011;28(1):41-7.

37. Palombo EA, Semple SJ. Antibacterial activity of traditional Australian medicinal plants. J Ethnopharmacol. 2001;77(2-3):151-7.

38. Cock IE. Antimicrobial activity of Eucalyptus major and Eucalyptus baileyana methanolic extracts. Int J Microbiol. 2009;6(1):31.

39. Chikowe G, Mpala L, Cock IE. Antibacterial activity of selected Australian Syzygium species. Pharmacog Commn. 2013;3(4):77-83. DOI: 10.5530/pc.2013.4.11

40. Tortora GJ, Funke BR, Case CL. Microbiology: An Introduction. Benjamin Cummings, San Francisco. 2001.

41. Vesoul J, Cock IE. The potential of Bunya nut as an antibacterial food agent. Pharmacog Commn. 2012;2(1):74-82. DOI: 10.5530/pc.2012.1.13

42. Cock IE. Antimicrobial activity of Acacia aulacocarpa and Acacia complanta methanolic extracts. Pharmacog Commn. 2012:2(1):66-71. DOI: 10.5530/ pc.2012.1.12
43. Cai L, Wu CD. Compounds from Syzygium aromaticum possessing growth inhibitory activity against oral pathogens. J Nat Prod. 1996;59(10):987-90.

44. Waage SK, Hedin PA. Quercetin 3-O-galactosyl-(1, 4, 6)-glucoside, a compound from narrow leaf vetch with antibacterial activity. Phytochem. 1985;24(2):243-5

45. Buzzini $P$, Arapitsas $P$, Goretti M, et al. Antimicrobial activity of hydrolysable tannins. Mini-Rev Med Chem. 2008;8(12):1179-87.

46. Wolinsky LE, Sote EO. Isolation of natural plaque-inhibiting substances from 'Nigerian chewing sticks'. Caries Res. 1984;18(3):216-25.

47. Hogg SD, Embery G. Blood-group-reactive glycoprotein from human saliva interacts with lipoteichoic acid on the surface of Streptococcus sanguis cells. Arch Oral Biol. 1982;27(3):261-8

48. Wu-Yuan CD, Chen CY, Wu RT. Gallotannins inhibit growth, water-soluble glucan synthesis and aggregation of Streptococci mutans. J Dent Res. 1988;67(1):51-

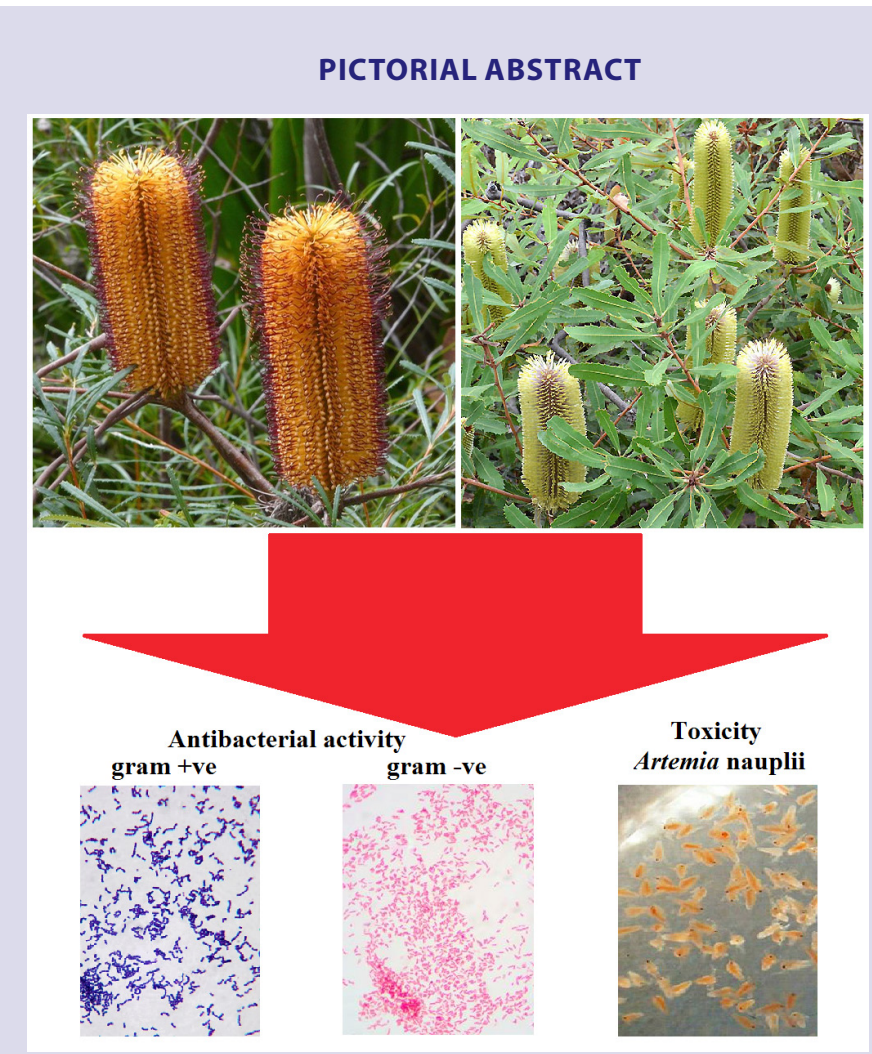

\section{SUMMARY}

- Methanolic B. collina and B. oblongifolia leaf extracts were screened for the ability to block the growth of a panel of bacteria.

- The growth inhibition of both gram-positive and gram-negative bacteria was tested.

- The antibacterial activity was quantified by determining the MIC values of each extract.

- $\quad$ Growth time course studies were also undertaken against $A$. faecalis and B. cereus.

- Toxicity of the B. collina and B. oblongifolia leaf extracts was determined using the Artemia nauplii toxicity bioassay.

\section{ABOUT AUTHORS}

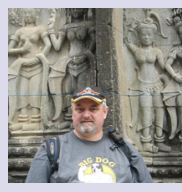

Dr. Ian Cock: leads a research team in the Environmental Futures Research Institute and the School of Environment and Science at Griffith University, Australia. His research involves bioactivity and phytochemical studies into a variety of plant species of both Australian and international origin, including Aloe vera, South Asian and South American tropical fruits, as well as Australia plants including Scaevola spinescens, Pittosporum phylliraeoides, Terminalia ferdinandiana (Kakadu plum), Australian Acacias, Syzygiums, Petalostigmas and Xanthorrhoea johnsonii (grass trees). This range of projects has resulted in nearly 200 publications in a variety of peer reviewed journals. 